\title{
Research Note \\ Ecotourism Land Tenure and Enterprise Ownership: Australian Case Study
}

\author{
Ralf Buckley \\ Director International Centre for Ecotourism Research, Griffith University, \\ Australia
}

\section{Introduction}

Ecotourism has been promoted widely as a potential tool in conservation and community development, in both developed and developing nations (Fennell, 1999; Weaver, 2001). In some instances at least, ecotourism has indeed contributed to conservation on private, community, or public lands outside the protected area estate (Buckley, 2003a; TOISTD, 2003; WTO, 2002). Elsewhere, however, tourism industry promoters have used the term ecotourism simply as an avenue to increase access to protected areas by commercial tourism operators, most recently under the guise of so-called partnerships (Buckley, 2002, 2003b). The outcomes of ecotourism hence depend not only on the ecotourism enterprise itself, but on the land or water where it operates. This aspect of the ecotourism sector, however, seems to have received rather little attention in the research literature. It has become contentious in Australia recently because of current political pressures to expand commercial tourism operations in protected areas (Australia DITR, 2003; Buckley, 2003b), and efforts to improve conservation on private land (Australia NTHT, 2003). Here, therefore, I examine the degree to which existing ecotourism enterprises in Australia operate on various different types of land tenure; and consider how these results may be relevant worldwide.

\section{Methods}

In 1999 we sent questionnaires to every outdoor tour operator listed in telephone directories throughout Australia, seeking information on gross annual turnover and various other financial statistics (Buckley, 1998). We also asked inter alia what land tenures they used. The response categories for this question were: national park, state (public) forest, private land, Aboriginal (community) land, leasehold pastoral land and 'other'. National parks included World Heritage areas, and 'other' categories included land owned by local government agencies. In order to obtain commercial information of this nature, we took careful precautions to ensure that questionnaire responses were anonymous. Geographical information requested, for example, was deliberately imprecise; and whilst some respondents provided detailed lists of operational sites, others did not. We did consistently receive information on the types of land tenure used. Overall, we received 217 useable responses to this question. Almost all the responses were from privatesector tourism operators and only these are reported here. 
Few respondents indicated what proportions of their operations took place on each of the different land tenure types they referred to, or the spatial extent of the areas concerned. For each completed questionnaire, therefore, the data available are simply a set of yes/no responses for each potential land tenure type. In analysing such data, the relative weightings attached to different responses are potentially critical. If one ecotourism enterprise operates only in national parks, whereas another operates in, say, three different land tenure types of which national parks are only one, should the two positive data points for the national park category be accorded equal weight, or should the latter receive only one third weighting? If two enterprises both use pastoral lands but one has 10 times the annual financial turnover of the other, should the two positive data points for pastoral lands be accorded equal weight, or should one receive 10 times the weighting? To examine whether the results are sensitive to such weightings, responses were examined using three different approaches.

In the first 'raw' approach, all records were treated equally, so that, for example, a record of a company operating on private land only was treated the same as a record of a company operating on private land but also elsewhere. In the second, 'proportional' approach, each company was given equal weight, so that records for a company operating on private land, parks and pastoral leases would be scored at one-third each. In the third, 'weighted' approach, the proportional data were weighted according to the approximate annual turnover of the company concerned, in four categories: $<\$ 10,000 \mathrm{pa}$, $\$ 10,000-\$ 100,000$ pa, $\$ 100,000-\$ 1,000,000$ pa and $\$ 1,000,000-\$ 10,000,000$ pa. All figures are in 1999 Australian dollars. Under this approach, records for a company in each turnover bracket received weightings of 1, 10, 100 and 1000 respectively.

\section{Results}

The response rate to the mail-out was only $10 \%$, and we cannot be certain that it was representative (Buckley, 1998). Based on these responses, results are as follows. By far, the majority of Australian outdoor tour operators use more than one type of land tenure: only $18 \%$ use only a single type, and many use three, four or more. Fewer than 5\% overall used pastoral leases, local government or other lands, and these are excluded from the analysis below. Raw responses indicate that $37 \%$ of outdoor tour operators in Australia use national parks, 26\% use private lands, 24\% use public forests and $13 \%$ use community lands (Table 1). There were no significant differences between revenue categories (chi-square test, $p>0.05$ ). Dividing records proportionately between multiple land tenure types intensifies these differences slightly: $43 \%$ in national parks, $26 \%$ on private lands, $21 \%$ in public forests and $10 \%$ on community lands (Table 2). Weighting by annual revenue suggests that ecotourism operations in national parks contribute $38 \%$ of total annual revenue, private lands $33 \%$, public forests $16 \%$ and community lands $13 \%$. For enterprises with annual turnover $>\$ 1 \mathrm{~m}$, approximately three quarters of their revenue derives from operations on parks or private lands and one quarter from public forests and community lands. For businesses with 
Table 1 Numbers of ecotourism enterprises in different income categories using different land tenures in Australia: Raw records

\begin{tabular}{|l|c|c|c|c|c|c||}
\hline \hline Raw & $<\mathbf{1 0 K}$ & $\mathbf{1 0 - 1 0 0 K}$ & $\mathbf{1 0 0 - 1 M}$ & $\mathbf{1 - 1 0 M}$ & Total & \% \\
\hline Park & 28 & 56 & 40 & 17 & 141 & 37 \\
\hline Private & 23 & 39 & 25 & 12 & 99 & 26 \\
\hline Forest & 18 & 39 & 25 & 8 & 90 & 24 \\
\hline Community & 9 & 20 & 14 & 7 & 50 & 13 \\
\hline Total & 78 & 154 & 104 & 44 & 380 & 100 \\
\hline
\end{tabular}

Table 2 Numbers of ecotourism enterprises in different income categories using different land tenures in Australia: Proportional allocation

\begin{tabular}{|l|c|c|c|c|c|c||}
\hline \hline Proportional & $<\mathbf{1 0 K}$ & $\mathbf{1 0 - 1 0 0 K}$ & $\mathbf{1 0 0 - 1 M}$ & $\mathbf{1 - 1 0 M}$ & Total & \% \\
\hline Park & 16 & 40 & 19 & 7 & 82 & 43 \\
\hline Private & 14 & 19 & 10 & 7 & 50 & 26 \\
\hline Forest & 9 & 16.5 & 11 & 2.5 & 39 & 21 \\
\hline Community & 4 & 8 & 5 & 2.5 & 19.5 & 10 \\
\hline Total & 43 & 83.5 & 45 & 19 & 190.5 & 100 \\
\hline
\end{tabular}

annual turnover $<\$ 1 \mathrm{~m}$, corresponding figures are approximately two thirds cf one-third.

The questionnaire responses also contained information on the geographic areas or regions where each tourism operation is based. Broadly, it seems that most businesses take advantage of all land tenures locally available. Aboriginal lands and pastoral leases are not uniformly distributed geographically, for example, so businesses are more likely to use these tenures in some regions than others. We did not ask respondents to estimate the spatial area of each land type they used. They may, for example, operate in a large national park plus a small private property nearby. Hence the figures above cannot be converted to area terms.

The principal conclusion from the data, therefore, and one which would appear to be reasonably robust, is that outdoor tourism operations in Australia are by no means restricted to a single land tenure such as protected areas. Rather, they use all available lands, with private land almost as popular as parks.

\section{Discussion}

The results given above are all for private-sector tourism operators. Worldwide, and indeed also in Australia, many ecotourism enterprises are also operated by public land management agencies, and by community and other organisations. Generalising the Australian approach presented above, we may classify ecotourism enterprises according to ownership categories, and operating areas according to land tenure type, so as to examine the interrelationships between the two.

Ecotourism enterprises may usefully be classified into four types, namely those owned by: 





- private businesses, such as companies, partnerships and individuals;

- communal groups, e.g. in Indigenous or tribal societies;

- not-for-profit and non-government organisations; and

- public agencies, including public land management agencies themselves.

Land tenure types may be classified in a similar way:

- private lands, freehold or long-term leasehold, often broad-acre rangelands and woodlands;

- communal lands, e.g. those held under traditional tenure systems or dedicated as Indigenous reserves;

- public lands allocated for primary production, such as forests and public rangelands; and

- public protected areas, including World Heritage sites, national parks and nature reserves.

Using these classifications, a matrix of the main possible combinations of land tenure and enterprise ownership is shown in Table 3. The table also indicates the approximate global frequency of each combination, based on case studies such as those in Buckley (2003a). Different combinations, however, appear to be more common in different countries, and these variations appear as regional ecotourism signatures. Many public land management agencies list tourism companies with relevant operating permits. There seem to be few if any comparative quantitative data, however, on the relative scale of ecotourism in different land tenures.

As part of ongoing analysis and debate into the significance of ecotourism for conservation and community development in various parts of the world, therefore, it would seem worthwhile to quantify the use of different land tenure types in different countries and regions, in addition to existing research on economics, enterprise, structures and management, policies and other aspects.

\section{Correspondence}

Any correspondence should be directed to R. Buckley, Director International Centre for Ecotourism Research, Griffith University, Parklands Drive, Southport Qld 4215, Australia (R.Buckley@griffith.edu.au).

\section{References}

Australia, Department of Industry Tourism \& Resources (2003) Pursuing Common Goals Opportunities for Tourism and Conservation. Report ITR 2003/070. ADITR, Canberra.

Australia, National Tourism and Heritage Taskforce (2003) Going Places: Developing Natural and Cultural Heritage Tourism in Australia. (2vv.) Environment Protection and Heritage Council, Canberra.

Buckley, R.C. (1998) International and Australian patterns in nature, eco and adventure tourism. National Ecotourism Conference 1998, Fraser Island.

Buckley, R.C. (2002) Public and private partnerships between tourism and protected areas. Journal of Tourism Studies 13, 26-38.

Buckley, R.C. (2003a) Case Studies in Ecotourism. Wallingford: CABI.

Buckley, R.C. (2003b) The practice and politics of tourism and land management. In R.C. Buckley, C.M. Pickering and D. Weaver (eds) Nature Tourism, Environment and Land Management. Oxford: CABI.

Fennell, D.A. (1999) Ecotourism: An Introduction. London \& New York: Routledge. 
Tour Operators Initiative for Sustainable Tourism Development (2003) Sustainable Tourism: The Tour Operators' Contribution. United Nations Environment Program Division of Technology Industry \& Economics, Paris.

Weaver, D.B. (2001) The Encyclopedia of Ecotourism. Wallingford: CABI Publishing.

World Tourism Organisation (2002) Sustainable Development of Ecotourism: A Compilation of Good Practices. Madrid: WTO. 